The

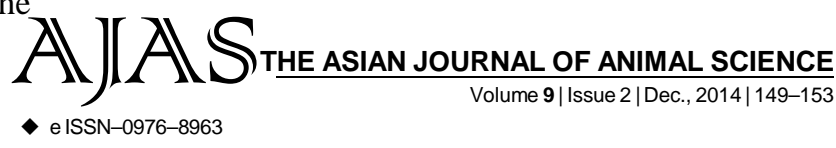

DOI : 10.15740/HAS/TAJAS/9.2/149-153

Visit us | www.researchjournal.co.in

RESEARCH ARTICLE.........

\title{
Pathology of gout induced by high protein diets in growing broilers
}

NITIN SINGH AND R.C. GHOSH

ABSTRACT...... The inestigation was carried out on the gross and histo-pathological changes that occur due to different protein diet in broilers. A total of 100, day-old broiler chicks were randomly divided into 5 groups having 20 chicks each. The chicks were fed with diets having 10 per cent (group A), 15 per cent (group B), 20 per cent (group C), 30 per cent (group D) and 40 per cent (group E) crude protein for 28 days. Post mortem examination of birds showed that relative weight of kidney was increased in birds of group E on day 28 post feeding. Grossly deposition of urate crystals in visceral

Author for Corresponding -

\section{NITIN SINGH}

Department of Veterinary

Pathology, College of Veterinary

Science and Animal Husbandry,

Anjora, DURG (C.G.) INDIA

Email: drnitinsinghvet@gmail.com

See end of the article for

Coopted authors' organs, petechial haemorrhages and enlargement of kidney were observed. The salient histopathological changes included tophi formation, severe degenerative and necrotic changes in kidney and mild fatty changes and necrosis of hepatocytes in liver. The histopathological changes in heart, spleen and bursa of fabricius in the birds of group E on day 14 were similar to the naturally gout affected birds.

KEY WORDS...... Haemato-biochemical changes, Gout, Poultry, High protein diet

HOW TO CITE THIS ARTICLE - Singh, Nitin and Ghosh, R.C. (2014). Pathology of gout induced by high protein diets in growing broilers. Asian J. Animal Sci., 9(2) : 149-153.

ARTICLE CHRONICLE - Received : 12.07.2014; Revised : 01.11.2014; Accepted : 17.11.2014 